\title{
Teaching the Politics of Islamic Fundamentalism*
}

\author{
Masoud Kazemzadeh, University of Alabama at Birmingham
}

Ever since the Iranian revolution of 1979 , in which a group of fundamentalist Shi'i clerics outmaneuvered liberals, socialists, and non-fundamentalist Islamists, Islamic fundamentalism has become the dominant force in much of the Islamic world. The rise of Islamic fundamentalism has generated several issues of analytical significance for political scientists.

Many scholars believe that Islamic fundamentalism will precipitate violent international conflicts (Karabell 1996-97). Samuel Huntington (1993) has gone so far as to argue not only that the coming clash between the West and the Islamic world will be the defining characteristic of the post-Cold War period but also that the Islamic world has "bloody borders" with Orthodox Christian, Hindu, Chinese, and African civilizations.

The collapse of communism has coincided with the emergence of democratic regimes in Latin America, Eastern Europe, and parts of Africa. However, the rise of Islamic fundamentalism may have retarded democratization in the Middle East. Islamic fundamentalist movements promise to replace incumbent authoritarian regimes with totalitarian ones which make political dissent blasphemy, assassinate their opponents, and carry out inquisitions of university professors, journalists, and intellectuals (Middle East Watch 1993). This has led the incumbent authoritarian regimes to halt or reverse earlier steps towards political liberalization and democratization. This situation has produced scholarly and popular debates on the relationship between democracy, Islam, and Islamic fundamentalism (see, for example, AbuKhalil 1995; Esposito and Piscatori 1991; Kazemzadeh 1996; Tessler and Brand 1995; Voll and Esposito 1995).

The misogynist programs of Islamic fundamentalists have provoked a backlash among many women who have organized resistance to funda- mentalist groups (Bennoune 1995; Mernissi 1988). At the same time, some women have embraced the veil and have become supporters of Islamist groups-both fundamentalist and anti-fundamentalist. The centrality of gender issues in contemporary Middle East politics has spawned scholarly and popular debates on the relationship between Islam, Islamic fundamentalism, and gender equality.

Both research and teaching on the subject of Islamic fundamentalism are very recent in political science because only in the past two decades have fundamentalist groups emerged as major political contenders. I see three main paradigms in the research on Islamic fundamentalism: Islamic Exceptionalism, Comparative undamentalisms, and Class Analysis.

\section{First Paradigm: Islamic Exceptionalism}

Scholars who adhere to the first paradigm believe that Western social scientific theories are inapplicable to the study of Islamic fundamentalism because this phenomenon is unique to the Islamic world. In other words, the Islamic world is essentially different from the rest of the world, in general, and the West, in particular. According to the first paradigm, Islam is comprised of a set of clearly defined and unchanging principles. This essentialist conception of Islam is combined with the assertion that Islam is not simply a religion but a comprehensive way of life. Moreover, this ahistorical and essentialist Islam is regarded as the independent variable determining the behaviors of the ruled and rulers alike.

According to Myron Weiner,

What is striking about the Islamic resurgence is its rejection of much of what is generally regarded as modern in the twentieth century: secularism, democracy, and even nationalism. In this respect Islam has come to play quite a different role from that of the religions of modernization-Christianity, Judaism, Confucianism, Shintoism, even Buddhism and Hinduism. Each of these religions, in its own way, has been interpreted or reinterpreted so as to induce people to behave in ways conducive to modernization, or to function alongside of, without impeding, modern behavior, yet to provide personal comfort, a sense of continuity with one's past, and a group identity. $(1987 \mathrm{~b}, 60)$

The scholars working within the first paradigm may be divided into three distinct subgroups. The division is primarily on political grounds. In other words, despite similar paradigmatic assumptions and conceptions, sharp political and policy differences divide adherents of the first paradigm. For lack of better terms, I refer to these subgroups as cultural relativists, neo-Cold warriors, and Islamic fundamentalists.

John Esposito is the most prolific and articulate representative of the cultural relativists. Members of this subgroup avoid using the term "fundamentalist" because they view the rise of Islamic movements in the past two decades as the latest resurgence of a cyclical phenomenon that has occurred throughout Islamic history (Esposito 1991). Instead, they refer to these movements as "Islamist," or "political Islam." Members of this subgroup tend to view Islam and Islamist movements in a very positive light. Concerned with the widespread negative prejudice against Islam and Muslims in the West, they dismiss much of the antidemocratic, misogynist, and atavistic policies of the fundamentalists as arising from either cultural differences or the temporary excesses of a few extremists (Rahnema and Behdad 1995).

However, most Western scholars who adopt the first paradigm belong to the second subgroup; they tend to have a very negative view of Islamic movements. Sadowski (1993) calls this group of scholars "Orientalist" and "neo-Orientalist." Because of the pejorative connotations which 
have come to accompany these terms, I prefer to use the culturally neutral term "neo-Cold Warriors" to refer to this group of scholars. They argue that the roots of dictatorship and repression of dissent in Islamic countries lie in Islamic faith and that Islamic fundamentalism is primarily a more assertive and political form of the Islamic faith. While Myron Weiner and Samuel Huntington do not make distinctions between Islam as a faith and Islamic fundamentalism as a political ideology, Daniel Pipes (1995, 1996) goes to great pains to make this distinction.

According to neo-Cold warrior scholars, Islamic fundamentalism represents the major threat to Western interests in the post-Cold War period (Pipes and Clawson 1992/93; Pipes 1995). First, fundamentalists threaten the stability of many proWestern regimes in the Middle East and North Africa, such as those in Egypt, Algeria, Jordan, Turkey, and Tunisia. Second, fundamentalists violently oppose the American-sponsored peace process between Israel and the Palestinian authority. Third, the most successful military and terrorist actions against Israelis and Americans have been carried out by fundamentalist groups such as (Lebanese) Hezbollah, (Lebanese) Islamic Amal, (Palestinian) HAMAS, and (Palestinian) Islamic Jihad. Fourth, there is a concerted coordination among fundamentalists that targets American interests. According to Daniel Pipes, "Teheran administers a network akin to an Islamist Comintern, making its role today not that different from Moscow's then" $(1995,193)$.

The third subgroup in the first paradigm is made up of Islamic fundamentalists themselves. According to Islamic fundamentalists, Islamic government is superior to democracy, and divine law is superior to the man-made laws of the Western legislatures. For Islamic fundamentalists, the Western liberal belief that society and government should not interfere in self-regarding acts (actions of an individual that affect no one but one's self) is harmful to a moral community. Islamic fundamentalists argue that a moral and believing society should repress individual activities such as drinking al- coholic beverages, playing games of chance and backgammon, engaging in pre-marital sex, and watching Baywatch or VH1, among others, which fundamentalists regard as harmful to the well-being of society. In other words, responsibility to the community should override notions of individual rights and liberties.

Shi'i clerics had always maintained that sovereignty belongs to God, who had invested it in the Prophet Mohammad who, in turn, had rele-

Both research and teaching
on the subject of Islamic
fundamentalism are very
recent in political science
because only in the past
two decades have
fundamentalist groups
emerged as major political
contenders.

gated it to the twelve Shi'i Imams one after another. Khomeini's innovation was to argue that during the absence of the 12th Imam (the Shi' $i$ Muslims' Messiah), sovereignty belongs to the Shi'i clerics. In July 1997, Ayatollah Mohammad Yazdi, chair of the Judicial Branch and one of the five most powerful men in Iran, said, "Religious leadership and political leadership are not separate from each other. Politics, government, and Islamic rule are for the clergy only and the non-clergy lack the right to interfere in politics" (1997, my translation).

Despite facing repression, the traditional Shi'i clerics-who constitute the overwhelming majority of high ranking clerics in Iran-continue to preach the millennia-long Shi'i belief that, as long as the 12th Imam is absent, the Shi'i clerics should avoid direct involvement in politics and only dwell on purely religious matters (Behrooz 1996; Kazemzadeh 1996). Sunnis, both traditional and fundamentalist, advocate the implementation of the Shariah (Islamic religious law), but do not advocate the rule of Sunni ulama or muftis (clerics).

As mentioned earlier, sharp political differences divide the three subgroups. Daniel Pipes, who is one of the most articulate of the neo-Cold warriors, regards the cultural relativists as both naive and appeasers who do not realize the dangers which Islamic fundamentalism poses. According to Pipes, "Communists and fundamentalists being invariably hostile to us, we should show not empathy but resolve, not goodwill but will power" $(1995,195)$. He advocates "containment and rollback" of Islamic fundamentalism. For Pipes, "fundamentalists challenge the West more profoundly than Communists did and do. The latter disagree with our politics but not with our whole view of the world" $(1995,194)$.

For cultural relativists, the neoCold warriors overestimate the threat of Islamic fundamentalism and underestimate the divisions among the fundamentalists (Esposito 1992; Mottahedeh 1995; Sick 1996).

The cultural relativists concede that, by and large, Islamic fundamentalists regard the United States as the enemy and that the fundamentalists are more than a mere nuisance. However, cultural relativists argue that it is hyperbole to regard Islamic fundamentalism as a threat to Western societies more dangerous than Communism. Islamic fundamentalists have not achieved nor are they ever likely to achieve the technological and military might that would be required to annihilate Western societies. The apparent consensus in Washington that Islamic fundamentalism should replace Communism as the mortal enemy in the postCold war period is the result of the confluence of three groups: the neoCold warriors who are presenting sophisticated theories; the old ideological Cold warriors who are looking for a new enemy; and bureaucrats in the defense and national security agencies who are seeking new missions to justify their role and avoid budgetary cutbacks (Sick 1996).

Gary Sick-who was the chief Iran specialist at the National Security Council under Presidents Ford, Carter, and Reagan and the princi- 
pal White House aide for Iran during the Iranian revolution-goes so far as to argue that not only is the neo-Cold warriors' picture of Iran as the instigator of much mischief wrong, but also that the policy of isolating the fundamentalist regime in Iran is constructed and advocated by Israeli officials and pro-Israeli interest groups in Washington. Moreover, Sick (1996) contends that these policies are harmful to the national security interests of the United States. Sick advocates a rapprochement between the United States and the fundamentalist regime in Iran.

\section{Second Paradigm: Comparative Fundamentalisms}

Scholars working within the second paradigm view the rise of Islamic movements in the past two decades as a part of the rise of the religious right around the globe. In other words, Islamic fundamentalism is but a part of a larger phenomenon. For example, it is argued that Islamic fundamentalism is not unique: one witnesses the rise of Christian fundamentalism in the United States, Jewish fundamentalism in Israel and the United States, the rise of Hindu fundamentalism in India, and the rise of militant, rightwing groups in countries like France,

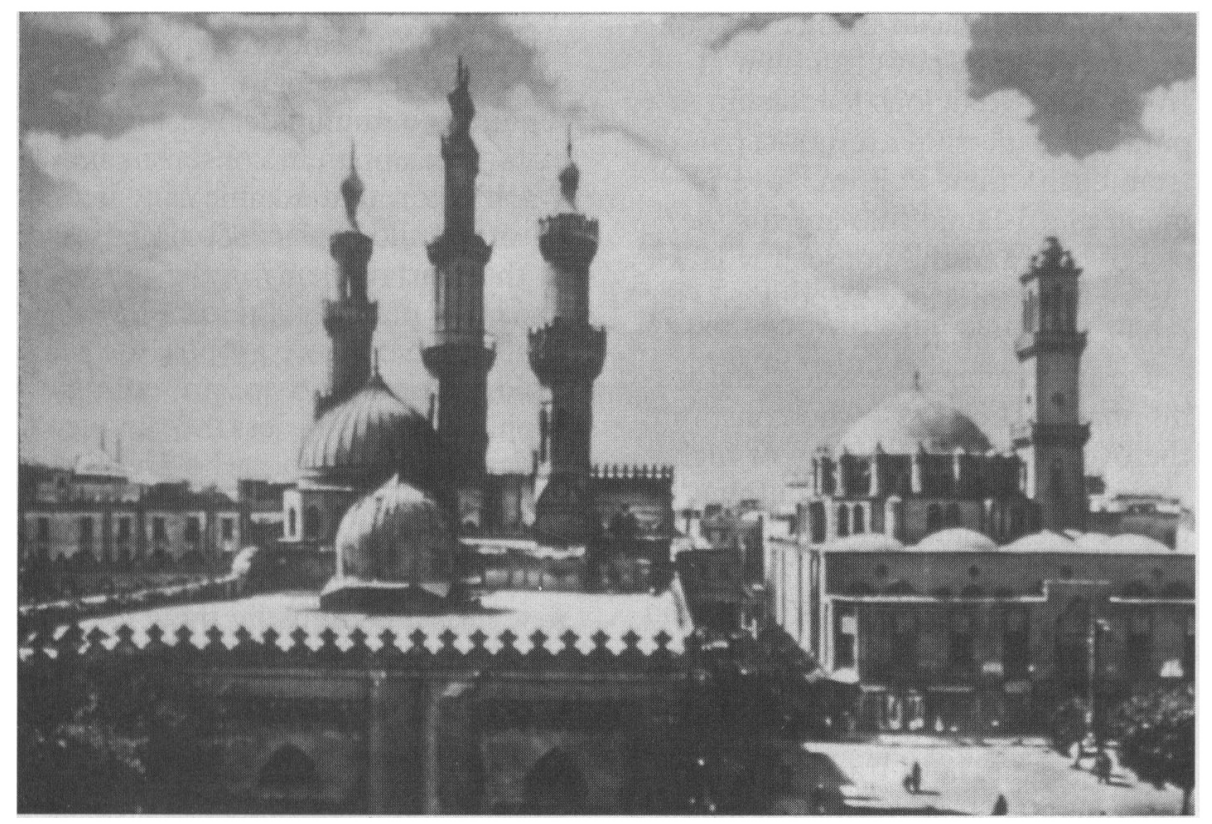

Al Azhar Mosque, Cairo

Photo Courtesy of Embassy of Arab Republic of Egypt
States. Scholars sharing this paradigm use social scientific theories to compare and contrast the various groups among the religious right (see, for example, Appleby 1997; Keddie 1995; Marty 1995; Marty and Appleby 1991).

Scholars who adopt the second paradigm tend to regard the various religious right movements as threats to democracy, civil liberties, women's rights, secular life, and scientific progress. Most proponents of the second paradigm tend to be mainstream scholars with moderate and liberal views. Religious right activists are very hostile to the notion that their respective movement is not unique because, as a rule, each religious fundamentalist group (whether Jewish, Christian, or Islamic) considers itself the sole possessor of The Absolute Truth. For many members of the religious right, the very notion of comparison with other fundamentalists is blasphemy (Marty 1995).

As far as I have been able to determine, before the 1990 s, only a few off-hand remarks in a few books and articles stated that there were some similarities among the various fundamentalist sects of the major Abrahamic religions. The extraordinary fruitful "Fundamentalism Project" conducted under the auspices of the American Academy of Arts and Sci-

ences and funded by the John D. 
They rarely compare Islamic fundamentalism with other religious movements. For these scholars, many of whom were born in Islamic countries, Islamic fundamentalism has very little relevance to traditional Islam. Many, if not most, tend to consider Islamic fundamentalism comparable to populist or fascist movements such as the KKK, the Nazis, or the Peronists. These scholars view Islamic fundamentalism as primarily a political movement among certain social classes to achieve political power for use in the interest of these classes.

Unlike the scholars working within the first paradigm, who consider socioeconomic class a Western construct inapplicable to the Middle East, and unlike the scholars in the second paradigm, who rarely use class analysis, the scholars embracing the third paradigm pay a great deal of attention to class and class struggle as primary explanatory factors in the rise of Islamic fundamentalism. Sami Zubaida (1993), Ervand Abrahamian (1993), Misagh Parsa (1989), and Fred Halliday (1996) are the major adherents of the third paradigm.

Most of the scholars in the third paradigm tend to regard Islamic fundamentalism as a major threat to democracy, civil liberties, women's rights, scientific progress, and secular life as well as to the civil rights of ethnic and religious minorities. Some of these scholars are practicing Muslims who regard the fundamentalists as a threat to the future of Islam, while most others tend to be atheists: most of the former are of Arab descent, whereas the overwhelming majority of the latter are scholars of Iranian origin teaching at universities in the West.

Scholars who utilize class analysis constitute a small minority of scholars of the Middle East. The field of Middle Eastern studies has always been dominated by perspectives that regard socioeconomic class as an epiphenomenon in the Middle East. It is argued that, unlike in the Western polities where feudal and capitalist classes have existed independently of the state and have tried to influence the state's policies to conform to their interests, in the Middle East, individuals and primordial groups (i.e., those related to kin, clan, or region) first gain hold of the state apparatus and then enrich themselves and become wealthy merchants, landholders, or capitalists (Bill 1972; Gran 1980).

In the early 1970 s, a small number of neo-Marxist and dependency school scholars specializing in the Middle East applied concepts of class and imperialism to account for politics in the region. Many scholars expected to see new social classes and modern associations (labor unions, teachers' associations, chambers of commerce, and the like) ushering in politics that were based on modern ideologies. However, the emergence of Islamic fundamentalist movements in the late 1970s and early 1980 s undermined the notion that politics in the Islamic world were class based.

Theda Skocpol, for example, who had earlier relied upon concepts of class and had explicitly denied any causal significance to superstructural variables (ideology, religion, and the like) completely reversed herself and argued that the Iranian revolution illustrated the saliency of the ideological factor (Skocpol 1973, 1979, 1982). Referring to Islamic fundamentalism, Myron Weiner wrote, "One striking feature of the new ideologies and movements, compared with the older ones, is the lack of explicit class content" (1987a, xxvi).

For scholars of the third paradigm, Khomeini's Islamic fundamentalism directly appealed to the mostazafin (the dispossessed) and was explicitly inimical to the mostakbarin (the exploiters). Although these lexicons were somewhat amorphous and certainly not as clearly well defined as the Marxian concepts of proletariat and bourgeoisie, there is nevertheless a strong class element to them. Like fascism, Islamic fundamentalist ideology is explicitly corporatist and organic (i.e., society is conceived of as an organic body where all parts have to cooperate in order to ensure the healthy functioning of the system). Like fascism, Islamic fundamentalism denies the saliency of class struggle and class consciousness and utilizes class-derived rhetoric to mobilize certain classes. Paraphrasing Karl Kautsky's description of Nazism as the social- ism of fools, Fred Halliday describes Islamic fundamentalism as "the antiimperialism of fools" $(1987,37)$.

After a decade-long hiatus, class analysis of Middle Eastern politics resurfaced in the 1990s. The third paradigm belongs to an emerging body of scholarship that uses social scientific concepts of class, the state, gender, and ideology to account for the rise of Islamic fundamentalism (see, for example, Moaddel 1993; Moghadam 1993; Moghissi 1996; Owen 1992; Paidar 1995).

\section{Hybrid Studies}

It is important to note that many scholars' works cannot be situated within the trichotomy discussed in this article. Having said that, I believe that these three paradigms are the main schools of thought on the study of Islamic fundamentalism. Other works that cannot be situated clearly within one of the three may be viewed as hybrids that combine various aspects of the main paradigms.

Dekmejian (1995), for example, uses Western social scientific theories associated with the second paradigm but operates within assumptions and conclusions that are similar to the cultural relativist subgroup in the first paradigm. In an insightful study, Halliday (1995) combines approaches taken from the second and third paradigms and finds striking ideological similarities among fundamentalists in Judaism, Christianity, and Islam without ascribing identical social class bases to them.

\section{Pedagogical Dilemmas}

In an introductory course entitled "Politics of Islamic Fundamentalism," which I taught in the Spring term of 1997, I faced the dilemma of teaching a course in which there is little scholarly consensus. Although discussing conflicting paradigms is common in graduate courses, many of us avoid discussing them in lowerdivision courses for fear that doing so might be too confusing for undergraduates.

I see two possible approaches to 
organizing such a course. In the first approach, one may organize the lectures and assign reading materials that are consistent with the paradigm that the instructor believes to be superior in that it raises the right questions and provides the best answers. The strength of this approach is that the instructor may go into great detail in discussing the various issues addressed by the paradigm. The major weakness of this approach is that the students may get the impression that there are no scholarly disagreements on the subject matter.

In the second approach, one may organize the lectures and assign reading assignments from all the paradigms. The strength of this approach is that it fosters critical thinking and empowers the students to choose the paradigm they find superior. The major weaknesses of the second approach are that the instructor loses some degree of authority and that the students may get the impression that all explanations are equally valid.

Ceteris paribus, and if John Stuart Mill was right when he said that "He who knows only his own side of the case, knows little of that," it might be a more fruitful pedagogical technique to follow the second approach. Our conceptual understanding of the term "paradigm" has been formed by Thomas Kuhn (1970) whose definition was based on physics, in which (allegedly) historically only one paradigm was dominant at a time. In political science, we do not have the same level of certainty that exists in physics. In the words of Robert Keohane:

Theories of world politics are not at all like those of physics. No careful analyst believes that our theories of world politics have attained either the explanatory quality or the practical usefulness of Newton's system, much less of quantum mechanics; and there is general skepticism that they will ever approximate the rigor and accuracy even of seventeenth-century physics. Furthermore, since both world politics and our values keep changing, there is no guarantee that even a well-tested theory will remain valid in the future $(1986,5)$.

In addition, political and ideological differences have often influenced the outcomes of debates in the social sciences, where paradigmatic assumptions, theories, conclusions, and policy ramifications may be tied to the economic and political interests of one group or another. Prominent political scientists Sheldon Wolin $(1968,1969)$ and Terence Ball (1976) have called attention to the necessity of recognizing the existence of competing paradigms as a longterm phenomenon in political science.

On the first day of the class, I had to ease the students into thinking in terms of competing paradigms. I told them to imagine that Rev. Pat Robertson and Rev. Jesse Jackson were asked to give lectures at a university in the Middle East. Both were asked to explain the pervasiveness of crime and teenage pregnancy in America to their Middle Eastern students. I solicited my students' views on what Robertson and Jackson would say. Using the Socratic method of debunking false starts and encouraging proper answers, I guided the students toward the anticipated conclusions.

The class reached the conclusion that for Robertson, banning of prayer in public schools was the main culprit. For Jackson, economic inequality and racism accounted for crime and teenage pregnancy. For example, for an indigent 16-year-old African American female growing up in a housing project with no prospects of attending college, finding above-minimum wage employment, or receiving health care, becoming pregnant would be a rational way of getting health care, food stamps, monthly cash payments, and housing subsidies. In other words, an atheist middle class White female teenager would not find it advantageous to become pregnant, while a believing Christian underclass African American female teenager might.

The students were asked what policies Robertson and Jackson would advocate to remedy the situation. The class concluded that Robertson would argue that reintroducing prayer and teaching abstinence in public schools and the media would reduce crime and teenage pregnancy and that Jackson would advocate full employment, universal health care, subsidized higher education, and policies to remedy racial discrimination.

Then I touched upon the thornier problem of why someone chooses one paradigm over another. The class discussed the relevance of the fact that Pat Robertson was a millionaire son of a millionaire who was a U.S. senator. Robertson would not benefit from the high income taxes that would be necessary to fund the programs Jackson's proposals would require. Jackson, on the other hand, was born in a housing project, the

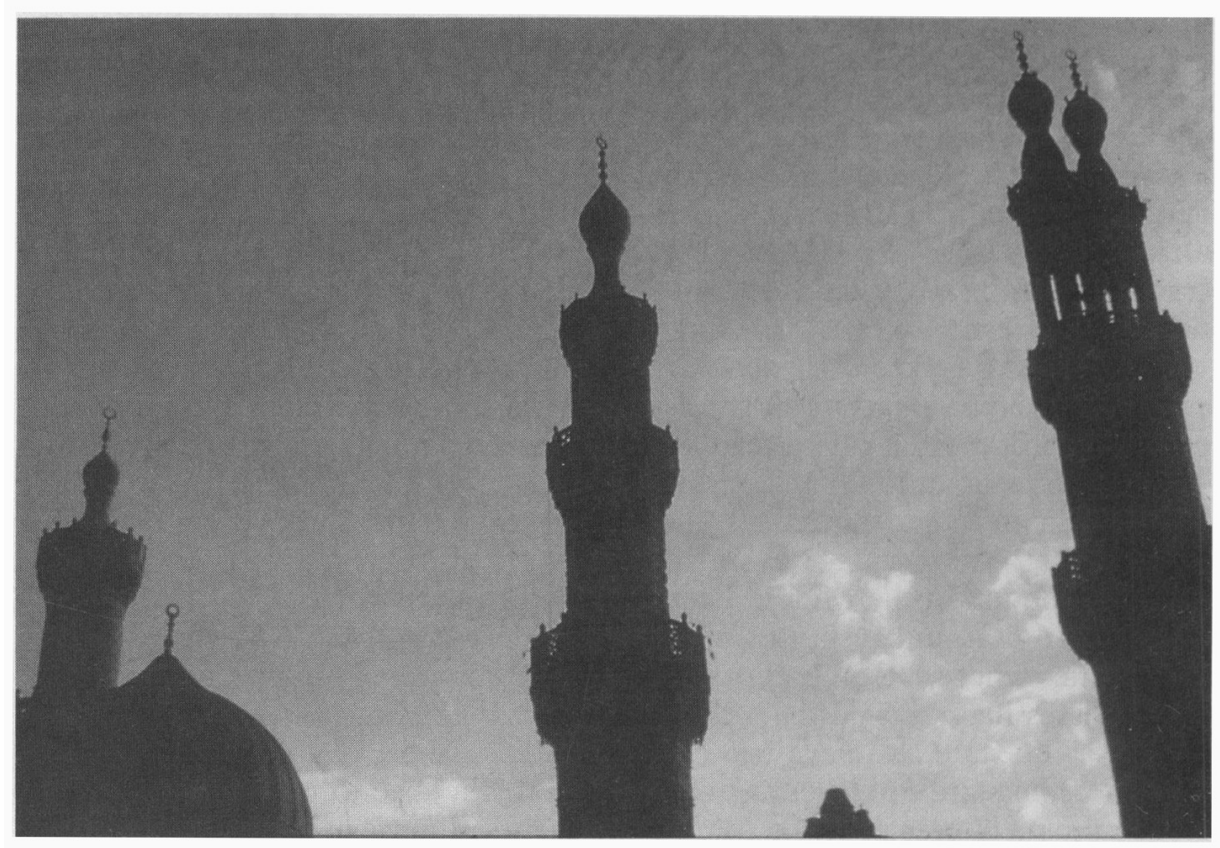

Photo courtesy of Embassy of Arab Republic of Egypt 
son of a teenage mother who was also born to a teenage mother. Jackson and the constituency he represents would not mind high income taxes on millionaires.

According to Mark Kann (1980), one's life situation and experiences affect one's preconceptions and evaluations of the political system. In other words, adopting a paradigm is neither wholly accidental nor totally innocent of social circumstances. As Kann succinctly put it, one who is born and raised in Beverly Hills perceives the police, the courts, the government, and the economic system differently than one who is born and raised in the barrios of East Los Angeles. In the words of David Easton (1969), "normative presuppositions" and "value assumptions" are part of all paradigms in political sciencebehavioralist, post-behavioralist, or otherwise. Our assumptions inform the theories we construct, and they in turn influence the policies we recommend (Maghroori and Ramberg 1982).

Finally, I asked how two Protestant ministers could come to diametrically opposed analyses and policy recommendations. I further inquired whether their disagreements might confuse students in the Middle Eastern university? By means of this 30minute exercise, I attempted to teach the students the meaning and implications of paradigms.

In teaching the course, I began by presenting the basic facts of the issue under discussion and then proceeded to present the conflicting interpretations and perspectives. The transition proceeded far more smoothly than I had hoped. The attempt succeeded in large part because there were 10 students in the class and most of them were juniors and seniors. I would have been quite apprehensive had the class contained 50 freshmen.

Throughout the quarter, I emphasized that there is more than one point of view on any given issue. Moreover, I encouraged, coaxed, and cajoled the students to make arguments for and against any particular explanation. For example, regarding the question of whether Islamic fundamentalism is a threat to American interests, each student had to make compelling arguments based on each paradigm and on the subgroups of the first paradigm. The same approach was taken to the question of whether Islam and Islamic fundamentalism are anti-democratic and whether Islam and Islamic fundamentalism are invariably misogynist. When discussing assigned readings - an article, a chapter in an edited book, or a book-the students were asked to place them in one of the paradigms.

As part of the final exam, each student was required to defend the conclusions of the paradigmatic group or subgroup that the student considered most valid. To my surprise, several of the students embraced the positions espoused by adherents of the second paradigm, Comparative Fundamentalisms. This was unexpected, considering the extent to which Islamic fundamentalism has been demonized in the West and in view of the fact that most American students have been socialized to view Muslims and Middle Easterners as the essentialist Other (Shaheen 1990; Tetreault 1996).

This could be explained by the fact that my students live in Alabama, the "Heart of Dixie," where the Christian Coalition alone boasts of having more than 40,000 members. Moreover, during the term I taught this course, a local county judge gained national attention for posting the Ten Commandments in his courtroom and opening court sessions by requiring those attending the proceedings to listen to a prayer by a local Christian minister. Judge Roy Moore, who rails against "those promoting homosexuality, abortion and those who want to abolish God from the American life by demanding the removal of 'In God We Trust' from dollar bills, 'Under One God' from the Pledge of Allegiance," presides in his courtroom a short 30 minute drive from the UAB campus (Moore 1997).

In response to a court ruling which regarded Judge Moore's posting of the Ten Commandments to be unconstitutional, the governor declared that he would call the Alabama National Guard to "defend the Commandments." Not to be outdone, the newly appointed attorney general rushed to provide justification for the judge's actions. Mean- while, the famous Ellen episode, in which the leading character comes out of the closet, was to be aired on national television. The local ABC affiliate was the only station in the country that did not air the show because the general manager deemed it inappropriate.

The pervasive power of the Christian Right and its ability and willingness to impose its views on others makes many non-fundamentalists in Alabama feel under siege. This, perhaps, might explain why these students were attracted to the second paradigm, which is highly conscious of the rise in religious fundamentalism around the world.

Moreover, I showed two taped programs that might have influenced the students' perceptions. One was an interview with the leader of Kahane Chai (a Jewish fundamentalist group in New York) on CBS's "60 Minutes" in which he had threatened a civil war against Prime Minister Rabin's government, a program which had aired a few months before a Jewish fundamentalist assassinated Rabin. The second tape was a CSPAN broadcast of a one-hour interview of Iran's President Rafsanjani by Mike Wallace of "60 Minutes" which was aired on March 26, 1997. The students expressed shock at the ferocity and extremism of Jewish fundamentalism and surprise at the moderation and reasonableness of Rafsanjani. When I asked, "Do you think that Jewish fundamentalists, Christian fundamentalists, and Islamic fundamentalists share striking similarities?" students unanimously responded "Yes." A fascinating discussion followed when I further inquired as to the specifics of those shared characteristics.

Selecting reading materials was not easy. Although there is an increasing number of fine articles on Islamic fundamentalism, only a few readers and edited volumes are available for classroom use. I could only find Winters (1995), Dudley (1992), Beinin and Stork (1997), Sidahmed and Ehteshami (1996) and Ruedy (1996). The last three are more appropriate for graduate courses, and Dudley's volume has only a few articles directly relevant for this course. If Islamic fundamentalism continues to be a significant force in poli- 
tics, we need more textbooks with which to better acquaint our students with a phenomenon which obviously animates policymakers, political scientists, and students alike.

\section{Note}

* I wish to thank Mary E. Guy, Carol B. Thompson, Mark E. Kann, Nora Hamilton, Laurie Brand, Gloria Badal, and the anonymous reviewers for their comments and criticisms, which have enriched this article. I am solely responsible for any errors of fact or interpretation.

\section{References}

Abrahamian, Ervand. 1993. Khomeinism: Essays on the Islamic Republic. Berkeley: University of California Press.

AbuKhalil, Asad. 1995. "The Islamic World Needs Secularism." In Islam: Opposing Viewpoints, ed. Paul A. Winters. San Diego: Greenhaven Press.

Appleby, R. Scott, ed. 1997. Spokesmen for the Despised: Fundamentalist Leaders of the Middle East. Chicago: University of Chicago Press.

Ball, Terence. 1976. "From Paradigms to Research Programs: Toward a Post-Kuhnian Political Science." American Joumal of POlitical Science 20(1): 151-77.

Behrooz, Maziar. 1996. "The Islamic State and the Crisis of Marja'iyat in Iran." Comparative Studies of South Asia, Africa and the Middle East 16(2): 93-100.

Beinin, Joel, and Joe Stork, eds. 1997. Political Islam: Essays from Middle East Report. Berkeley: University of California Press.

Bennoune, Karima. 1995. "Islamic Fundamentalism Represses Women." In Islam: Opposing Viewpoints, ed. Paul A. Winters. San Diego: Greenhaven Press.

Bill, James A. 1972. "Class Analysis and the Dialectics of Modernization in the Middle East." International Joumal of Middle East Studies 3(4): 417-34.

Dekmejian, R. Hrair. 1995. Islam in Revolution: Fundamentalism in the Arab World. 2nd ed. Syracuse: Syracuse University Press.

Dudley, William. ed. 1992. The Middle East: Opposing Viewpoints. San Diego: Greenhaven Press.

Easton, David. 1969. "The New Revolution in Political Science." American Political Science Review 63(4): 1051-61.

Esposito, John L. 1991. Islam and Politics. 3rd ed. Syracuse: Syracuse University Press. 1992. The Islamic Threat: Myth or Reality. New York and Oxford: Oxford University Press.

_ , and James P. Piscatori. 1991. "Democratization and Islam." Middle East Journal 45(3): 427-40.

Gran, Peter. 1980. "Political Economy as a Paradigm for the Study of Islamic History." International Journal of Middle East Studies 11:511-26.

Halliday, Fred. 1987. "The Iranian Revolution and Its Implications." New Left Review 166(Nov/Dec): 29-37.

1995. "Fundamentalism and the Contemporary World." Contention: Debates in Society, Culture, and Science 4(2): 41-58.

- 1996. Islam and the Myth of Confrontation: Religion and Politics in the Middle East. London: I.B. Tauris Publishers.

Huntington, Samuel P. 1993. "The Clash of Civilizations?" Foreign Affairs 72(3): 22-49.

Kann, Mark E. 1980. Thinking About Politics: Two Political Sciences. St. Paul and New York: West Publishing Company.

Keddie, Nikki. 1995. "Comparative Methods in the Study of 'Fundamentalism'." Presented at the 1995 Annual Meeting of the Middle East Studies Association, Washington, D.C.

Karabell, Zachary. 1996-97. "Fundamental Misconceptions: Islamic Foreign Policy." Foreign Policy 105(Winter): 77-90.

Kazemzadeh, Masoud. 1996. "The State, Civil Society and the Prospects of Islamic Fundamentalism." Comparative Studies of South Asia, Africa and the Middle East 16(1): 55-67.

Keohane, Robert O. ed. 1986. Neorealism and Its Critics. New York: Columbia University Press.

Kuhn, Thomas S. 1970. The Structure of Scientific Revolutions. 2nd ed. Chicago: University of Chicago Press.

Maghroori, Ray, and Bennett Ramberg. 1982. Globalism Versus Realism: International Relations' Third Debate. Boulder: Westview Press.

Marty, Martin E. 1995. "Comparing Fundamentalisms." Contention: Debates in Society, Culture, and Science 4(2): 19-39.

- _ and R. Scott Appleby, eds. 1991. Fundamentalisms Observed. Vol. 1 of The Fundamentalism Project. Chicago: University of Chicago Press.

___ eds. 1993a. Fundamentalisms and Society: Reclaiming the Sciences, the Family, and Education. Vol. 2 of The Fundamentalism Project. Chicago: University of Chicago Press.

__ eds. 1993b. Fundamentalisms and the State: Remaking Politics, Economics, and Militance. Vol. 3 of The Fundamentalism Project. Chicago: University of Chicago Press.

—_ eds. 1994. Accounting for Fundamentalisms: The Dynamic Character of Movements. Vol. 4 of The Fundamentalism Project . Chicago: University of Chicago Press.

hended. Vol. 5 of The Fundamentalism Project. Chicago: University of Chicago Press.

Mernissi, Fatima. 1988. "Muslim Women and Fundamentalism." Middle East Report 18(4): 8-11, 50.

Middle East Watch. 1993. Guardians of Thought: Limits on Freedom of Expression in Iran. New York: Human Rights Watch.

Moaddel, Mansoor. 1993. Class, Politics, and Ideology in the Iranian Revolution. New York: Columbia University Press.

Moghadam, Valentine M. 1993. Modernizing Women: Gender and Social Change in the Middle East. Boulder: Lynne Rienner Publishers.
Moghissi, Haideh. 1996. Populism and Feminism in Iran: Women's Struggle in a MaleDefined Revolutionary Movement. New York: St. Martin's Press.

Moore, Roy. 1997. Sermon on Memorial Day at Jerry Falwell's Thomas Road Baptist Church, broadcast on Birmingham's TCI Cable Channel 10.

Mottahedeh, Roy. 1995. "The Islamic Movement: The Case for Democratic Inclusion." Contention: Debates in Society, Culture, and Science 4(3): 107-27.

Owen, Roger. 1992. State, Power and Politics in the Making of the Modern Middle East. London and New York: Routledge.

Paidar, Parvin. 1995. Women and the Political Process in Twentieth-Century Iran. Cambridge and New York: Cambridge University Press.

Parsa, Misagh. 1989. Social Origins of the Iranian Revolution. New Brunswick: Rutgers University Press.

Pipes, Daniel. 1995 "Political Islam Is a Threat to the West." In Islam: Opposing Viewpoints, ed. Paul A. Winters. San Diego: Greenhaven Press.

- 1996. "The Muslim Exceptionalism." Presented at the 1996 Annual Meeting of the American Political Science Association, San Francisco.

_-, and Patrick Clawson. 1992/93. "Ambitious Iran, Troubled Neighbors." Foreign Affairs 72(1): 124-41.

Rahnema, Saeed, and Sohrab Behdad. 1995. "Introduction: Crisis of an Islamic State." In Iran after the Revolution: Crisis of an Islamic State, ed. Saeed Rahnema and Sohrab Behdad. London and New York: 1.B. Tauris Publishers.

Ruedy, John, ed. 1996. Islamism and Secularism in North Africa. New York: St. Martin's Press.

Sadowski, Yahya. 1993. "The New Orientalism and the Democracy Debate." Middle East Report 23(4): 14-21.

Shaheen, Jack G. 1990. "Our Cultural Demon-The 'Ugly Arab'." The Washington Post, August 19, C1-C2.

Sick, Gary. 1996. "The United States and Iran: Truth and Consequences." Contention: Debates in Society, Culture, and Science 5(2): 59-78.

Sidahmed, Abdel Salam, and Anoushiravan Ehteshami, eds. 1996. Islamic Fundamentalism. Boulder: Westview Press.

Skocpol, Theda. 1973. "A Critical Review of Barrington Moore's Social Origins of Dictatorship and Democracy." Politics and Society 4(1): 1-34.

1979. States and Social Revolutions: $A$ Comparative Analysis of France, Russia, and China. Cambridge: Cambridge University Press.

_. 1982. "Rentier State and Shi'a Islam in the Iranian Revolution." Theory and Society 11(3): 265-83.

Tessler, Mark, and Laurie Brand. 1995. Democracy and Islam in Arab Politics. Pew Case Studies in International Affairs. Case 611. Institute for the Study of Diplomacy Publications, School of Foreign Service, Georgetown University.

Tetreault, Mary Ann. 1996. "Deconstructing the Other: Teaching Politics of the Middle 
East." PS: Political Science and Politics 29(4): 696-700.

Voll, John, and John Esposito. 1995. "Islam Has Strong Democratic Traditions." In Islam: Opposing Viewpoints, ed. Paul A. Winters. San Diego: Greenhaven Press. Weiner, Myron. 1987a. "Introduction." In Understanding Political Development, ed. Myron Weiner and Samuel P. Huntington. Boston: Little, Brown and Company. - 1987b. "Political Change: Asia, Africa, and the Middle East." In Understanding Political Development, ed. Myron Weiner and Samuel P. Huntington. Boston: Little, Brown and Company.

Winters, Paul A. ed. 1995. Islam: Opposing Viewpoints. San Diego: Greenhaven Press.
Wolin, Sheldon S. 1968. "Paradigms and Political Theories." In Politics and Experiences: Essays Presented to Michael Oakeshott, ed. Preston King and B. C. Parekh. Cambridge: Cambridge University Press. -. 1969. "Political Theory as a Vocation." American Political Science Review 63(4): 1062-82.

Yazdi, Ayatollah Mohammad. 1997. "The Non-Clergy Do Not Have the Right to 'Interfere' in Politics." Speech Excerpted in Iran Times, July 25, 1.

Zubaida, Sami. 1993. Islam, the People and the State: Political Ideas and Movements in the Middle East. London and New York: I.B. Tauris Publishers.

\title{
Battling the Six Evil Geniuses of Essay Writing
}

\author{
Charles King, Georgetown University
}

Essay questions, term papers, "takehome" finals, research papers, and project reports are standard components of most political science courses. Professors may ask students to write an essay as part of a midterm of final exam, or to hand in extended papers completed outside class that have required substantial research in the university library or elsewhere. These kinds of assignments not only give professors a chance to evaluate students' skills as writers and critical thinkers they also give students a chance to reflect seriously on contentious issues at the heart of the study of politics: What is democracy? What makes people vote for Party A and not for Party $B$ ? Do ideas affect the way people behave politically? Why do revolutions occur? How do states interact in the international arena? What determines the shape of a state's foreign policy? Why do countries go to war?

But university students are smart, sometimes too smart by half. They have learned several tricks of the essay-writing trade and are all too willing to employ them, especially when it comes to answering essay questions on exams. These tricks are thought to be sure-fire techniques for writing essays and getting passing grades, for they have been tried and tested by generations of firstyear college students, including many of the students' professors during their own college days. These tricks are all, however, inspired by one of at least Six Evil Geniuses of Essay Writing. By falling prey to one of the Evil Geniuses, students are guaranteed of getting less than full points for their work; more importantly, signs that the Evil Geniuses are at work normally convince professors that students value getting a passing grade over learning.

Students, especially in introductory courses, should be encouraged to avoid the company of the Six Evil Geniuses and to beware their evil ways. This article exposes the work of these devilishly clever fiends and offers hints for students and professors on how to resist their wiles. Most teaching professionals are already intimately familiar with the Evil Geniuses, either because they have graded essays in which these characters have been at work or, more disturbingly, because they themselves have succumbed to their charms during periods of intellectual weakness. This article presents one framework for addressing some of the key concerns undergraduates have about writing essays in political science courses, a framework which I have used to good effect when teaching my own introductory political science sections.

\section{About the Author}

Masoud Kazemzadeh teaches political science at the University of Alabama at Birmingham. $\mathrm{He}$ is the recipient of the Western Political Science Association's "Best Dissertation in Political Science Award" for 1996. He also received an Honorable Mention from the Foundation for Iranian Studies for the "Best Dissertation of the Year on a Topic of Iranian Studies" (1996). He is the author of Why Khomeini? Class and Gender in the Rise of Islamic Fundamentalism in Iran (forthcoming).

\section{Identifying the Six Evil Geniuses}

The Six Evil Geniuses of Essay Writing come in many different forms, but their main avatars are described below. Examples of each of the Genius's "best" work are also provided.

\section{Evil Genius No. 1: The Sycophant}

The Sycophant thinks that if he butters up the reader-by commenting positively on the lectures or on the reading assignments-the professor will be likely to ignore the content of the essay itself. For example:

Question: Why are political scientists concerned with the concept of "political culture"?

Essay: In their brilliant, path-breaking work, Almond and Verba address the concept of political culture. As Professor Jones demonstrated in her excellent and stimulating lecture, the concept of political culture is important. By using it, as Professor Jones cogently argued, political scientists can explain a number of political phenomena....

Sycophantism is, of course, a bad idea. Essays like this read more like the minutes of a Soviet communist party congress than a response to an exam question. The fact that a professor has assigned a particular read- 